\title{
Determinant Factor for Quality Green Open Space Assessment in Malaysia
}

\author{
Nurhayati Abdul Malek*1, Siti Zabeda Mohammad ${ }^{1}$ and Amanina Nashar ${ }^{2}$ \\ ${ }^{I}$ Centre of Studies for Landscape Architecture, Faculty of Architecture, Planning and \\ Surveying, Universiti Teknologi MARA Cawangan Selangor Kampus Puncak Alam, 42300 \\ Bandar Puncak Alam, Selangor, Malaysia. \\ ${ }^{2}$ Research Division, MDLA Design Sdn. Bhd., 21-2, Jalan Elektron E U16/E, Denai Alam, \\ 47810 Shah Alam, Selangor \\ *nurhayati8203@salam.uitm.edu.my
}

Received: 2 January 2018 Final Version Received: 6 December 2018

\begin{abstract}
Green open spaces (GOS) are an integral part of the green network in any urban areas which serve the benefits of cities and people's well-being in a various form including physical, emotional and social health. Embrace the fact that the green open space is one of the key indicators to sustainable city planning; yet, many countries including Malaysia are facing underutilised parks issues due to various factors including the quality aspect of the parks. Before this, evidence suggests that sustainability and quality of city's dwellers are measured by the quality and quantity aspects of parks and open spaces. Hence, this paper sought to explore further on the determinant factors of quality green open space (QGOS) assessment in Malaysia as part of an effort to overcome this shortcoming. This study adopts quantitative method through questionnaire survey to identify the most relevant factors which influence the quality of green open spaces in Malaysia. 1500 questionnaire survey was distributed within fifteen (15) Neighborhood Parks. The results generated from Exploratory Factor Analysis (EFA) had revealed eight most relevant factors of social sustainability, use pattern, place attachment, facilities, safety and security, nature preferences, activities and accessibility to achieve the quality of open spaces in Malaysia. Hence, it is hoped that the findings from this review would contribute to the improvement of Malaysian neighbourhood parks and plan as part of the support for the 11th Malaysian Plan (2016-2020).
\end{abstract}

Keywords: Quality, Green Open Space (GOS), Neighbourhood Park, Quality Green Open Space (QGOS), Quality of Life (QOL)

\section{INTRODUCTION}

The worrisome numbers of non communicable diseases among Malaysian, with underutilised park issues are among critical challenges that need to be taken seriously by the government. A current report released by Ministry of Health (2016) indicates the drastic increasing prevalence of non-communicable disease since 1990 to 2016 which due to unhealthy lifestyle among Malaysian citizen besides other external factors, such as food intakes, genetics and physical activities performed. The high number and risk of NCD's are expected to remain high in future.
Responding to this issue, the healthy living for the people is included as one of the essential criteria in the second strategy of Malaysian National Development Strategy (MyNDS) of the 11th Malaysian Plan (2016-2020), which listed under sustainable well-being plan. Malaysian government in collaboration with other related parties such as landscape architect and planners had produced more comprehensive national town and country planning policies and several relevant action plans in the country's development plans. The goal is to provide the necessary physical and social infrastructure to improve the quality of life (Ting, 2001). Indeed, in line with this notion, the actual thrust of our National 2020 
Vision Policy, also stresses on the social agenda as a key component in the formulation of economic policies, where the ultimate measure of economic success is the achievement of higher living standards and the well-being of the people. Together with this effort, this notion seeks to support the $11^{\text {th }}$ Goal of Sustainable Development Goals (SDGs) under United Nations Development Programme (UNDP), particularly on sustainable cities and communities. Among the initiatives are to create green public spaces, and improve urban planning and management comprehensively. The UNDP is an organisation which fully gives it full support towards Malaysia development plans, for instance, the $11^{\text {th }}$ Malaysian Plan (2016-2020). All of the plans above are to encourage more citizens to involve with a healthier lifestyle and reducing the number of people with NCD's diseases. Hence, improving the Malaysian quality of life (QOL) indexes.

Parks or green open spaces function as social places for people from various background and ages to enjoy being outdoors (Pretty et al., 2007; Lo \& Jim, 2012; Amine, Norsidah \& Ismail, 2017). Recreational opportunities, social engagement, healthy lifestyle, cultural values, mind relaxations are those countless benefits people obtained from parks experiences (Karuppannan \& Sivam, 2013; Suhardi, 2015; Siti Rasidah, Norizan \& Siti Syamimi, 2015; Kapoor \& Putta, 2017; Paul \& Nagendra, 2017). Considering numerous benefits offers by parks or GOS, this implies that a good QGOS will enhance people's living quality particularly for health and physical improvement. Indeed, urban theories agreed that quality, distance, legibility, comfort, maintenance, activities, safety and accessibility are the significant factors to green open spaces utilisation (Ewing, Handy, Brownson, Clemente \& Wiston, 2006; Ewing \& Handy, 2009; Karuppannan \& Sivam, 2013). Numerous studies on factors influences of GOS, evidence that nature elements is one of the significant factors to influence park utilisation and user's attraction to the parks (De Vries, Verheij, Groenewegen, Spreeuwenberg, 2003; Jim \& Chen, 2006; Zhang, van Dijk, Tang \& Berg, 2015; Paul \& Nagendra, 2017).

These studies are supported by a study conducted by Yang and Kang (2005), suggest that a high quality of recreational spaces should be build up with nature sounds as compared to urban sounds, for instance, vehicles and construction noise as it will influence the space utilisation among its users. The study further elaborated that a decrease in nature sounds, cause a decrease in park surrounding qualities. In other studies, Karuppannan and Sivam (2013), point out that a QGOS would generate high space utilisation among its user's. A possible explanation for these is due to the facts that natural elements create a human attachment to particular parks as it is evidence to improve human well being, psychical and psychological well being. This statement is empirically supported by other studies, which confirmed that green open space utilization is highly related to decreasing stress level, improving physical activities, rapid surgeries and mental health recovery (Takano, Nakamura \& Watanabe, 2002; Bratman, Hamilton \& Daily, 2012, European Commission, 2013; Seltenrich , 2015). Hence, it is important for planners and park designers like Landscape Architects to explore the knowledge on the determinant factors of QGOS for future park development and as part of an effort to support the Malaysian National Development Strategy (MyNDS).

\section{LITERATURE REVIEW}

One of the key aspirations outlines in National Landscape Policy (NLP) is to produce a quality, unique, and sustainable landscape to accomplish the Beautiful Garden Nation vision. It is believed, that the implementation of this vision comprehensively would enhance people's quality of life and their environments. Hence, NLP had evidenced that landscape development as an essential requirement in national physical development. During the past 20 years, various information has become available on the quality of life (QoL). QoL and wellbeing are used interchangeably and inconsistently within studies (De Leo et al., 1998). According to Malaysian Economic Planning Unit (EPU), well-being as the physical, social and economic benefits which contributes to QoL development (Aisyah, Mariana, Syahriah \& Mansor, 2016). Good health and attractive environment are two significant measures contribute to the wellbeing of Malaysian citizen through QGOS, particularly in this paper neighbourhood park. Several past studies had an address on the subject of quality offers and user's behavioural reaction towards it.

As mentioned by Baker and Crompton (2000), a study conducted by Parasuraman, Zenithal and Berry (1985), suggests that the word 'quality' as an evaluation or perception towards a service, through numbers of experience with it. When the high quality of outdoor recreation services is achieved, it indicates that the 
visitor's needs of recreation opportunities are met (Manning, 1986; as cited in Mackay and Crompton, 1990). This implication suggests that the increase in high quality of green open spaces resulted in high level of user's satisfaction, hence increase the GOS utilisation. In this paper, it is believed that a good QGOS will cause an increase in people's well-being and satisfaction when performing the recreational activities. To our knowledge, open space utilisation is strongly influenced by the quality of GOS. This statement is supported by studies conducted on green open spaces within Asian cities, where the authors agreed that QGOS would increase the frequency of park visits and utilisation of spaces in within among its users (Karuppannan \& Sivam, 2013; Siti Rasidah, Norizan \& Siti Syamimi, 2015). The work of Nurhayati, Manohar, \& Mustafa Kamal (2012) had revealed that till today, the planning and design factors of neighbourhood parks and green open spaces remains elusive and it is not being discovered yet. In parks and open space studies, urban theorist believed that several urban design criteria which influence parks utilization were highly related to factors such as location, safety, distance, park size, accessibility, park maintenance, comfort, legibility, types of activities and facilities provided (Ewing, Handy, Brownson, Clemente, \& Wiston, 2006; Poortinga, 2006; Chan \& Lee, 2009; Ewing \& Handy, 2009; Sugiyama., Francis, Middleton, Owen, Giles-Corti, 2010; Taylor et.al, 2011; Paquet et al., 2013, Akpınar, 2014).

Numerous researchers highlighted the social, ecosystem and environmental values offer by GOS to its users (Amine, Norsidah \& Ismail, 2017). According to Siti Rashidah, Norizan, \& Siti Syamimi (2015), four prominent factors which contribute to successful green open spaces are good of access and linkage, comfort and image, utilisation and activities and sociability. Similarly, Carr et al. (1992) stated that activities or recreational opportunities offers are among the needs of people in open spaces. In this paper; it is believed that GOS particularly neighbourhood parks should encourage active involvement of parks users, human and human interaction as well as human and nature interaction. A study conducted by Sari \& Isami (2012), revealed that people involved in GOS enhanced their sense of wellbeing and increased the attachment towards the parks. Meanwhile, the work of Von Kursell's, (1997), indicates that Neighbourhood Parks as spaces approximately between 0.5 to the 0.8 kilometer radius, which functions as local parks that offer various passive and active recreational opportunities as well as sufficient facilities for a diverse group of people. Similarly, Chapman (1999) had extended the notion of neighbourhood park as a space located at the development centre, where various needs are met, and it can reach within a sensible distance, which equipped by basic recreational facilities for all group of people.

Hence, the scope of this review will particularly refer to parks which offer recreational opportunities for both local and the immediate communities, located within a community neighbourhood residential area. In this review, the quality of GOS will specifically highlights the category of a Neighbourhood Park and is specifically defined as 'a successful public green open spaces, that comply the needs of its user's, located within a residential neighborhood area that is beyond the usual outdoor recreation and leisure expectations' (Nurhayati, Manohar, Mustafa Kamal \& Azlizam, 2011).

\section{METHODOLOGY}

This study undertakes on quantitative approaches using a questionnaire survey. A total 1500 questionnaire surveys were distributed among the users of 15 selected neighbourhood parks under ten municipal jurisdictions with a total population of 5.7 million in 2010 , within Klang Valley. All 15 neighbourhood parks are selected due to its aim to be ranked as 20 most livable cities worldwide including economic aspects. Moreover, all of the selected parks are situated within concentrated areas of urbanisation and economic activities, which planned to demonstrate sustainable cities (Figure 1).

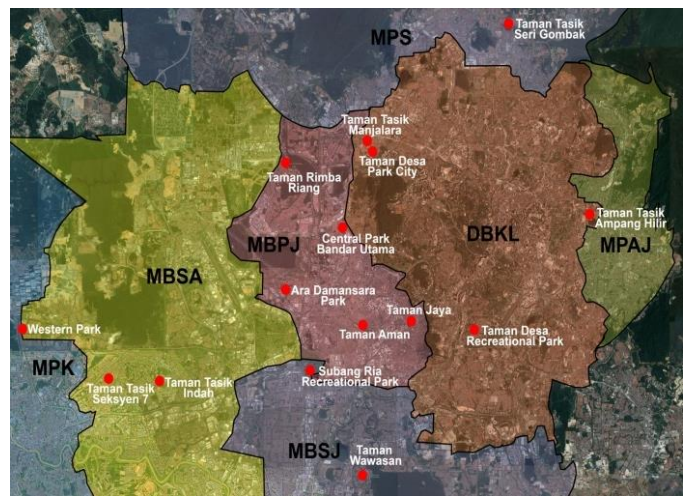

Fig. 1: Map indicates the distribution of all 15 $\mathrm{NP}$ and municipalities boundaries in Klang Valley involved in this study. (Source: Author, 2014; Google Earth Pro) 
Preliminary inventory on each existing neighbourhood parks; its size, jurisdiction and location in districts such as Petaling Jaya, Kuala
Lumpur, Shah Alam, Gombak, Subang Jaya, Ampang, Klang and are gathered as presented in

Table

Table 1: Inventory of Neighbourhood Parks in Klang Valle

\begin{tabular}{|c|c|c|c|}
\hline Name of Parks & Location & Size & Jurisdiction \\
\hline \multirow{5}{*}{$\begin{array}{l}\text { 1. Taman RimbaRiang } \\
\text { 2. Taman Aman } \\
\text { 3. Taman Jaya } \\
\text { 4. Central Park Bandar Utama } \\
\text { 5. AraDamansara Park }\end{array}$} & Section 9, Kota Damansara & 4.45ha & MBPJ \\
\hline & Petaling Jaya & 5.2 ha & MBPJ \\
\hline & Petaling Jaya & 10.7 ha & MBPJ \\
\hline & Bandar Utama, Petaling Jaya & 4 ha & MBPJ \\
\hline & Ara Damansara & 9.9. ha & MBPJ \\
\hline \multirow{2}{*}{$\begin{array}{l}\text { 6. Taman Desa Park City } \\
\text { 7.Taman TasikManjalara }\end{array}$} & Kepong & $13 \mathrm{ha}$ & DBKL \\
\hline & Manjalara & 8.15 ha & DBKL \\
\hline \multirow{3}{*}{$\begin{array}{l}\text { 8.TamanRekreasiTasikSeksyen } 7 \\
\text { 9.Western Park } \\
\text { 10.Taman Rekreasi Indah } \\
\end{array}$} & Seksyen 7, Shah Alam & $18 \mathrm{ha}$ & MBSA \\
\hline & Setia Alam & 4.35 ha & MBSA \\
\hline & Shah Alam & 7.5 ha & MBSA \\
\hline \multirow{3}{*}{$\begin{array}{l}\text { 11.Taman Wawasan } \\
\text { 12.Taman Desa Recreational Park } \\
\text { 13.Subang Ria Recreational Park }\end{array}$} & Puchong & 11.1 ha & MPSJ \\
\hline & Desa Petaling & $2.26 \mathrm{ha}$ & MPSJ \\
\hline & Subang Jaya & $15.3 \mathrm{ha}$ & MPSJ \\
\hline 14.Taman Tasik Seri Gombak & Gombak & 18.5 ha & MPS \\
\hline 15.Taman Tasik Ampang Hilir & Ampang & 16.5 & MPAJ \\
\hline
\end{tabular}

(Source: author, 2016)

Meanwhile, the questionnaire survey was divided into four sections with 45 questions on five-point Likert-scales. Section A, B and C required the respondent to rate on neighbourhood park qualities, utilisation and satisfaction level. Section D asked about their background. Earlier, based on the critical reviews on park-related studies, all of the possible related QGOS factors were crystallised and thematised accordingly. 15 significant criteria which made relevant to QGOS were selected and included in the questionnaire survey (Diagram 1). The questionnaire survey was distributed evenly with a total number of 100 respondents sample for each neighbourhood park randomly among park users.

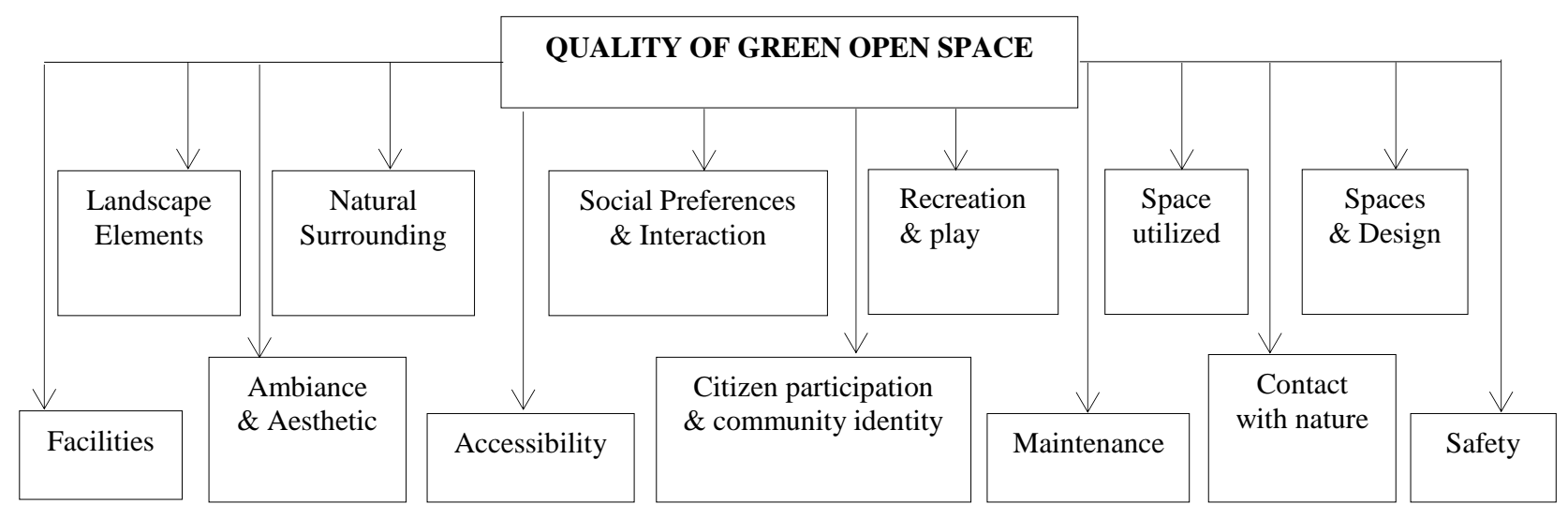


Diagram 1: Variables used for questionnaire survey of quality of green open space (QGOS) in Malaysia

\section{RESULTS}

\subsection{SAMPLING ADEQUACY.}

Exploratory factor analysis (EFA) is applied in to reveal the latent factors underlying the quality of neighbourhood parks. A principal axis factoring using Promax rotation was computed to on all the statements to confirm the appropriateness of conducting factor analysis (Tabachnick \& Fidell, 2001). A series of the statistical requirements were met. The results from Barlett's test of sphericity $(p=0.000)$ and the Kaiser-Meyer-Olkin measures of sampling adequacy $(\mathrm{KMO}=0.734)$ specified that the data was very appropriate for EFA (Table 2). Each remain factors were based on following criterion of (Pallant, 2007):

- Eigenvalues that greater than 1.0 (Kaiser Criterion)

- Factor loadings greater than 0.50

- Scree plot

- Factors with at least three items and

KMO and Bartlett's Test

Kaiser-Meyer-Olkin Measure $\quad .734$

of Sampling Adequacy.

Bartlett's Test Approx. of Sphericity

\begin{tabular}{|l|l}
\hline $\begin{array}{l}\text { Approx. } \\
\text { Chi-Square }\end{array}$ & 15629.056 \\
\hline df & 351 \\
\hline Sig. & .000 \\
\hline
\end{tabular}

important structure coefficients

- The conceptual significance of the factors

Table 2: Kaiser-Meyer-Olkin (KMO) and Bartlett's Test of Sphericity.

\subsection{DETERMINANT FACTORS TO QUALITY GOS}

The result indicated there were 24 items related to user's perception and satisfaction based on 15 criteria of QGOS. In this paper, only items with factor loading at least 0.5 and above are considered as significant from the factor matrix result. Table 3 demonstrates factor analysis summary results computed. From the data in Table 3, it is apparent that eight latent factors were revealed from three main themes of park quality, utilisation and overall satisfaction of QGOS. The factors were named based on the subthemes that were found in each factor. The park user's perception and satisfaction reported for about $67.094 \%$ of the total variance. The factor loading for the eight factors is from 0.525 to 0.858 (Table 3). Meanwhile, the majority of all items correlated at least 0.3 with $(\mathrm{p}<0.05)$, suggesting good factorability. None of the correlations (r) was greater than 0.9. Hence, none of the items was subjected to the singularity. The Cronbach alpha of all extracted factors exceeded 0.6. Therefore, the scale achieved internal consistency. The commonalities for all items exceed 0.3, suggesting the 'ability' of the items to load strongly in one of the factors.

Table 3: Factor Analysis Summary Results.

\begin{tabular}{|c|c|c|c|c|}
\hline & $\begin{array}{l}\text { Factor } \\
\text { loading }\end{array}$ & $\begin{array}{c}\text { No. } \\
\text { of } \\
\text { items }\end{array}$ & $\begin{array}{l}\text { Cronbach's } \\
\text { alpha( } \alpha)\end{array}$ & $\begin{array}{c}\% \text { of the } \\
\text { total } \\
\text { varian } \\
\text { ce } \\
\end{array}$ \\
\hline $\begin{array}{l}\text { Factor 1: Social } \\
\text { sustainability }\end{array}$ & & 6 & .809 & 16.345 \\
\hline $\begin{array}{l}\text { I am very } \\
\text { satisfied with this } \\
\text { park }\end{array}$ & .767 & & & \\
\hline $\begin{array}{l}\text { The park size is } \\
\text { enough for the } \\
\text { whole community }\end{array}$ & .688 & & & \\
\hline $\begin{array}{l}\text { I would rate this } \\
\text { park to have high } \\
\text { overall quality }\end{array}$ & .681 & & & \\
\hline $\begin{array}{l}\text { Sufficient } \\
\text { recreation and } \\
\text { leisure activities } \\
\text { to residents }\end{array}$ & .619 & & & \\
\hline $\begin{array}{l}\text { I have only good } \\
\text { things to say } \\
\text { about this park }\end{array}$ & .606 & & & \\
\hline $\begin{array}{l}\text { will continue } \\
\text { using this park in } \\
\text { future }\end{array}$ & .525 & & & \\
\hline $\begin{array}{l}\begin{array}{l}\text { Factor 2: } \\
\text { pattern }\end{array} \\
\end{array}$ & & 3 & .736 & 28.891 \\
\hline $\begin{array}{l}\text { I dislike the water } \\
\text { sound }\end{array}$ & .832 & & & \\
\hline $\begin{array}{l}\text { I only utilise the } \\
\text { park for } \\
\text { particular events }\end{array}$ & .759 & & & \\
\hline $\begin{array}{l}\text { The park has too } \\
\text { many trees }\end{array}$ & .682 & & & \\
\hline $\begin{array}{l}\text { Factor } 3 \text { : Place } \\
\text { attachment }\end{array}$ & & 4 & .736 & 39.050 \\
\hline $\begin{array}{l}\text { I often spend time } \\
\text { in the } \\
\text { wooded/forest } \\
\text { area in this park }\end{array}$ & .657 & & & \\
\hline I like to fish here & .612 & & & \\
\hline $\begin{array}{l}\text { I usually relax } \\
\text { alone by the } \\
\text { pond/sit on the } \\
\text { grass }\end{array}$ & .548 & & & \\
\hline $\begin{array}{l}\text { Celebrate } \\
\text { birthday/BBQ } \\
\text { with friends\& } \\
\text { family here }\end{array}$ & .526 & & & \\
\hline $\begin{array}{lll}\text { Factor } & 4 & \text { : } \\
\text { Facilities } & & \\
\end{array}$ & & 2 & .798 & 47.260 \\
\hline $\begin{array}{l}\text { Facilities for } \\
\text { sports should be } \\
\text { provided }\end{array}$ & .775 & & & \\
\hline
\end{tabular}




\begin{tabular}{|c|c|c|c|c|}
\hline $\begin{array}{l}\text { This park needs } \\
\text { more planned } \\
\text { activities }\end{array}$ & .766 & & & \\
\hline $\begin{array}{l}\text { Factor 5 : safety } \\
\text { \& security }\end{array}$ & & 3 & .764 & 53.253 \\
\hline $\begin{array}{l}\text { There are enough } \\
\text { facilities for } \\
\text { OKU/disable }\end{array}$ & .855 & & & \\
\hline $\begin{array}{l}\text { The park is a } \\
\text { disable / OKU } \\
\text { friendly park }\end{array}$ & .709 & & & \\
\hline $\begin{array}{l}\text { The park lighting } \\
\text { enhance my } \\
\text { safety during } \\
\text { night time }\end{array}$ & .641 & & & \\
\hline $\begin{array}{lll}\text { Factor } \quad 6 & : \\
\text { Nature } & & \\
\text { preferences } & \\
\end{array}$ & & 2 & .810 & 58.481 \\
\hline $\begin{array}{l}\text { The park needs a } \\
\text { lot more trees }\end{array}$ & .853 & & & \\
\hline $\begin{array}{l}\text { This park needs } \\
\text { more matured } \\
\text { and big trees }\end{array}$ & .834 & & & \\
\hline $\begin{array}{ll}\text { Factor } 7: \\
\text { Activities }\end{array}$ & & 2 & .786 & 63.252 \\
\hline $\begin{array}{l}\text { I walk in this } \\
\text { park every day }\end{array}$ & .858 & & & \\
\hline $\begin{array}{l}\text { I do my jogging } \\
\text { here every day }\end{array}$ & .742 & & & \\
\hline $\begin{array}{ll}\text { Factor } & 8: \\
\text { Accessibility } & \end{array}$ & & 2 & & \\
\hline $\begin{array}{l}\text { Location of a } \\
\text { park is not } \\
\text { important }\end{array}$ & .841 & & .724 & 67.094 \\
\hline $\begin{array}{l}\text { Accessibility is } \\
\text { not important. } \\
\text { Therefore I don't } \\
\text { mind the park is } \\
\text { far away }\end{array}$ & .687 & & & \\
\hline
\end{tabular}

Table 3 above demonstrate summary of factor analysis result for fifteen (15) neighbourhood parks in Malaysia on the quality of green open spaces. As mentioned earlier, this paper aims to explore the determinant factors of quality green open spaces, which based on the user's perceptions and satisfaction level. The result had proven that eight factors, which include social sustainability, use pattern, place attachment, accessibility, safety and security, nature preferences, activities and distance, were the essential factors to high quality green open spaces. Social sustainability is the significant subtheme which proven to contribute for high QGOS (Eigenvalue $=4.41$, Variance Explained $=16.345 \%)$, followed by use pattern (Eigenvalue $=3.39$, Variance Explained $=$ $28.891 \%$ ), place attachment (Eigenvalue $=2.74$, Variance Explained $=39.050 \%$ ), facilities $($ Eigenvalue $=2.22$, Variance Explained $=$ $47.260 \%$ ), safety and security (Eigenvalue = 1.62 , Variance Explained $=53.253 \%$ ), nature preferences (Eigenvalue $=1.41$, Variance Explained $=58.481 \%)$, activities (Eigenvalue $=$ 1.30 , Variance Explained $=63.252 \%$ ), and accessibility (Eigenvalue $=1.04$, Variance Explained $=67.094 \%$ ) respectively .

\section{DISCUSSIONS}

In this paper, social sustainability is accessed through recreational opportunities and park user's experiences based on their satisfaction level. In achieving a successful and highquality park, it is important for the parks to provide sufficient recreational opportunities through facilities and spaces which meet the needs of the park user's. A sufficient number of recreational opportunities promotes social sustainability and increase the social interaction among the neighbourhood park user's (AlBishawi \& Ghadban, 2011; Nor Zalina, Khalilah, Mazlina \& Khairunnisa, 2014). Types of activities offered at the parks determine the social cohesion among its users. A possible explanation to this is that social cohesion is accessed through the frequency of contact between individuals and the interaction that exist (Carmona, Tiesdell, Heath, \& Oc, 2010 \& Gehl, 2011). It implicates that a park that offers activities which encourage interaction between its users is categorised as a park that considers social sustainability in its design, for instance, activities such as picnicking, camping or gathering spaces. Moreover, the findings presented in Table 3, had supported the previous study which indicated that the increase in satisfaction level increased people well-being and improving the quality of life (Argyle, 2001; Lavallee et al., 2007).

Similarly, the findings on use pattern, place attachment, nature preferences and activities also supported the theory of human needs on open spaces by Matsuoka and Kaplan (2008), which extracted three themes under nature needs. These needs include interaction with nature, visual attractiveness and recreation opportunities. Indeed, several past and currents studies had also evidence that nature elements boost positive psychological, health and well being effects to human (Selhub \& Logan, 2012; Rabiatul Adawiyah, Sabarinah \& Azni , 2013; Bruton \& Floyd, 2014; Jackson, Daniel, McCorkle, Sears \&Bush, 2013; Wolf \& Robbins, 2015; Kondo, South \& Branas, 2015; Cohen-Cline, Turkheimer \& Duncan, 2015). Interestingly, the findings of this study provide important insight which supports the aforementioned 11th Goal of Sustainable Development Goals (SDGs) under United Nations Development Programme (UNDP) particularly improving the urban planning and management comprehensively for a healthier community. Hence, this study evidence that social sustainability is one of the essential aspects to be included in neighbourhood park planning process in future to achieve the QGOS in Malaysia. 
As shown in table 3, the second factor, use pattern is indicated through space utilisation and attractiveness towards surrounding park spaces. In the same vein, Nurhayati, Manohar \& Nik Ismail (2015) in their study, found a significant relationship between quality of green open space, use patterns as well as the satisfaction of park users. An increase in park utilisation indicates an improvement in people's health and physical condition. A growing number of studies had addresses on the importance of parks in improving people's quality of life (Pawinee, Kardi, Jian\& Kazunori, 2005; Jim \&Chen, 2006; Nurul, Rosilawati, Faizah \& Norzailawati, 2014). Hence, this implies that a successful and high-quality park generates high utilisation among its user's. Indeed, a recent study conducted by Karuppannan and Sivam(2013), also found that a high quality of parks boosts high numbers of park visits and utilisation. The findings also suggested that a high quality of parks should offer active, healthy living among its users. This notion is supported by Tahvanainen et al. (2001), who agreed that a basic foundation of quality of open spaces encourages active involvement among its user's as well as generates the feeling of excitement of being outdoors.

Meanwhile, place attachment factor seeks on human and nature interaction. The findings also indicate that safety and security as part of important measures to high QGOS. A possible explanation to this is that, according to the theory of Maslow (1954), on human needs, he outlined six categories of needs, where safety and cognitive-aesthetic (the need to learn and to appreciate beauty) is one of the essential basic human needs. It is, therefore, worth saying that, safety factors, as well as aesthetic aspect under place attachment factor, should be included to produce a quality GOS design. The evidence presented in Table 3 suggested that activities type which comprises of passive and active is identified as one of the prominent factors which contribute to a quality of GOS. A study on parks selection criteria conducted in Saga City, Japan revealed that the resident quality of life is influenced by the quality of the park, which measures through types of activities and user's needs (Pawinee, Kardi, Jian \& Kazunori, 2005). It is indicated that a high-quality park invites high numbers of users and its utilisation through various types of activities offers. Therefore, these reviews provide important insights on the association of parks activities offers about park utilisation. The research also implies that; a quality of neighbourhood park design should consider all types of users from a different age group in park activities planning for future references. Similarly, this notion is supported by other study conducted by Nurazlina, Nurhayati \& Mazlina (2016), which agreed that activities offer in the neighbourhood parks would influence parks utilisation among its residents besides frequency of visit and duration of stay.

The result obtained from the findings in Table 3 , also revealed that distance as one of the essential criteria for quality GOS. In this paper, distance factor is measured by parks location and accessibility aspect. In contrary, Amine, Norsidah \& Ismail (2017), argues that high accessibility does not indicate through park distance, where distance and accessibility do not correlate to each other. Meanwhile, there are other studies indicates that accessibility is highly associated with distance and park location and should be highly considered in park design. This notion is supported by Pawinee, Kardi, Jian \& Kazunori (2005), Jim \& Chen (2006), Nurhayati, Manohar \& Mustafa Kamal(2011), and Nurazlina, Nurhayati \&Mazlina (2016), who agreed that accessibility is one of the prominent factors to quality of neighbourhood park or green open space, which indicated through distance and park location aspects.

\section{CONCLUSION}

Successful green open spaces are an outdoor setting that functions beyond a normal recreational space. It is a place which supports the user's needs, ensures social sustainability, psychological treatment and boundless outdoor experiences enfold with a sense of comfort, safety, social cohesion and invites regular visits in future among its users. However, the absentees of these eight significant qualities of GOS which include social sustainability, use pattern, place attachment, facilities, safety, nature preferences, activities offers and high accessibility had caused numerous parks and open spaces provided remain underutilised particularly in the Malaysian context. Without the understanding of a criterion to produced high GOS, our parks and open space far to achieve permanently successful. Hence, this paper provides essential insight on the determinant factors to high QGOS as an important step to re-look and see what was left behind and what improvements or continuing efforts could be made. It equates to the needs 
of providing a quality of Malaysia GOS which is the aim of this study.

\section{REFERENCES}

Aisyah Abu Bakar, Mariana Mohamed Osman, SyahriahBachok, \&Mansor Ibrahim. (2016). Investigating Rationales of Malaysia Quality of Life and Wellbeing Components and Indicators. Procedia Social and Behavioral Sciences, 222,132 142.

https://doi.org/10.1016/j.sbspro.2016.05.20 2

Akpinar, A. (2014). Assessing the users'perceptions, preferences, and reasons for the use of urban greenway. Journal of the Faculty of Forestry Istanbul University, $64 \quad$ (2), 41-55. http://dx.doi.org/10.17099/jffiu.31281.

Al-bishawi, \&Ghadban, S. (2011). A methodological approach for reading urban open space.International Journal of Architectural Research, 5(1):7385.http://dx.doi.org/10.26687/archnetijar.v5i1.219

Amine Moulay, Norsidah Ujang\& Ismail Said. (2017). Legibility of neighbourhood parks as a predictor for enhanced social interaction towards social sustainability. Cities, 61, 58-64. https://doi.org/10.1016/j.cities.2016.11.007

Argyle, M. (2001). The Psychology of happiness. London: Rutledge.

Bratman, G. N., Hamilton, J. P., \& Daily, G. C. (2012). The impacts of nature experience on human cognitive function and mental health. Annals of the New York Academy of Sciences, 1249(1), 118-136. https://doi.org/10.1111/j.17496632.2011.06400.x

Bruton, C.; Floyd, M. (2014). Disparities in built and natural features of urban parks: Comparisons by neighbourhood level race/ethnicity and income. Journal of Urban Health, 91, 894-907. https://doi.org/10.1007/s11524-014-9893-4

Carr, S., F., M., Rivlin, L.G., \&Stone, A.M. (1992). Public Spaces. New York, NY: Cambridge University Press.

Carmona, M., Tiesdell, S., Heath, T., \& Oc, T. (2010). Public places- urban spaces: The dimensions of urban design. London: Routledge.

Chan, E.H.W. and Lee, G.K.L. (2009).Design considerations for environmental sustainability in high-density development: A case study of Hong Kong. Environment Development and Sustainability, 11(2),
359-374.

http://dx.doi.org/10.1007\%2Fs10668-0079117-0

Chapman, G.A.(1999). Design Variables and the Success of Outdoor Neighbourhood Recreational Facilities. Unpublished Master Thesis, the University of Arizona, Arizona. Retrieved from https://repository.arizona.edu/handle/1015 $0 / 278696$

Cohen-Cline, H.; Turkheimer, E.; Duncan, G.E. (2015). Access to green space, physical activity and mental health: A twin study. Journal of Epidemiology and Community Health, 69, 523-529. https://doi.org/10.1136/jech-2014-204667

De Leo, D. R., et al. (1998). LEIPAD: An internationally applicable instrument to assess the quality of life in the elderly. Medicine, 24, 1727.https://doi.org/10.1080/0896428980959 6377

De Vries, S.; Verheij, R.A.; Groenewegen, P.P.; Spreeuwenberg, P. (2003). Natural environments - healthy environments? An exploratory analysis of the relationship between green space and health. Environment and Planning A: Economy and Space, 35, 1717-1731. https://doi.org/10.1068/a35111

EC (2013), Communication from the Commission to the European Parliament, the Council, the European Economic and Social Committee and the Committee of the Regions Green Infrastructure (GI) Enhancing Europe's Natural Capital, Retrieved from http://eurlex.europa.eu/legalcontent/EN/TXT/?uri=CELEX: 52013DC0249.

Ewing, R. and Handy, S. (2009). Measuring the unmeasurable: urban design qualities related to walkability. Journal of Urban Design, 14(1), 6584.https://doi.org/10.1080/1357480080245 1155

Ewing, R., Handy, S., Brownson, R.C., Clemente, O., \&Wiston, E. (2006). Identifying and measuring urban design qualities related to walkability.Journal of Physical Activity and Health, 3(1), 223240. https://doi.org/10.1123/jpah.3.s1.s223

Gehl, J. (2011). Life between buildings: Using public spaces. London: The John Hopkins University Press.

Jackson, L.; Daniel, J.; McCorkle, B.; Sears, A.; Bush, K. (2013). Linking ecosystem services and human health: The eco-health relationship browser. International Journal 
of Public Health, 58, 747-755. https://doi.org/10.1007/s00038-013-0482-1

Jim, C. Y., \& Chen, W. Y. (2006).Recreationamenity use and contingent valuation of urban green spaces in Guangzhou, China, Landscape and urban planning, 75(1), 8196.https://doi.org/10.1016/j.landurbplan.20 04.08.008

Kapoor, S., \& Putta, V. (2017).Interrelation of Public Open Spaces and Social Behavior: A Chronological Perspective. Understanding Built Environment, 55-62. https://doi.org/10.1007/978-981-10-21381_6

Karuppannan, S.,\&Sivam, A.(2013) Comparative analysis of utilisation of open space at the neighbourhood level in three Asian cities: Singapore, Delhi and Kuala Lumpur.Urban Design International, $18(2)$, $145-$ 164.https://doi.org/10.1057/udi.2012.34

Kondo, M.; South, E.; Branas, C. (2015). Nature-based strategies for improving urban health and safety. Journal Urban Health, $1-15$. https://doi.org/10.1007/s11524-015-9983$\mathrm{y}$

Lavallee, L. F., Hatch, P. M., Michalos, A. C. \& Mckinley, T. (2007).Development of the contentment with life assessment scale (class): Using daily life experiences to verify levels of self-reported life satisfaction.Social Indicators Research, 83, 201-244. https://doi.org/10.1007/s11205006-9054-6

Lo, A.Y.; Jim, C.Y. (2012). Citizen attitude and expectation towards greenspace provision in the compact urban milieu.Land Use Policy, 29, 577586.https://doi.org/10.1016/j.landusepol.20 11.09.011

MacKay, K.J., \& J.L. Crompton, (1990).Measuring the Quality of Recreation Services. Journal of Park and Recreation Administration, 8(3), 47-56.

Matsuoka, R. H., \& Kaplan, R. (2008).People needs in the urban landscape: analysis of landscape and urban planning contributions. Landscape and urban planning, 84(1), 7 19.https://doi.org/10.1016/j.landurbplan.20 07.09.009

Nor Zalina Harun, Khalilah Zakariya, Mazlina Mansor \& Khairunnisa Zakaria. (2014). Determining attributes of urban plaza for social sustainability. Procedia- social and behavioral sciences. 153, 606-615. https://doi.org/10.1016/j.sbspro.2014.10.09 3

Nurazlina Abu Bakar, Nurhayati Abdul Malek\&MazlinaMansor.(2016). Access to Parks and Recreational Opportunities in Urban Low-income Neighbourhood.Procedia-Social and Behavioral Sciences, 234, 299-308. https://doi.org/10.1016/j.sbspro.2016.10.24 6.

Nurhayati Abdul Malek, Manohar Mariapan, \& Nik Ismail Azlan Ab Rahman. (2015). Community participation in a quality assessment for green open spaces in Malaysia.Procedia-Social and Behavioral Sciences, 168 , 219-228 https://doi.org/10.1016/j.sbspro.2014.10.22 7

Nurhayati Abdul Malek, ManoharMariapan, \& Mustafa Kamal Mohd Shariff. (2012). The Making of a Quality Neighbourhood Park: A Path Model Approach.Procedia - Social and Behavioral Sciences, 49, 202 - 214. https://doi.org/10.1016/j.sbspro.2012.07.01 9

Nurhayati Abdul Malek, Manohar Mariapan \& Mustafa Kamal Mohd Shariff \& Azlizam Aziz (2011). Assessing the needs for a quality neighbourhood park. Australian Journal of Basic and Applied Sciences,5(10):743-753.

Nurul Salleh, A., RosilawatiZainol, Faizah Ahmad \&Norzailawati Mohd Noor. (2014). Factors that Contribute to Green Neighbourhood: A Review. International Journal of Property Sciences, 4 (1), retrieve from https://ajba.um.edu.my/index.php/IJPS/arti cle/view/4593

Pallant, J. (2010). SPSS survival manual: A step by step guide to data analysis using SPSS, McGraw-Hill International.

Paquet, C., Orschulok, T.P., Coffee, N., Howard, N.J., Hugo, G., Taylor, A.W., Daniel, M. (2013). Are accessibility and characteristics of public open spaces associated with better cardiometabolic health? , Landscape Urban Planning, 118,70-78.

Parasuraman, A. P, Zeithaml V. A. \&Berry, L. L.(1985). A Conceptual Model of Service Quality and its Implications for Future Research. Journal of Marketing, 49(4), 4150.https://doi.org/10.2307/1251430

Paul, S., \&Nagendra, H. (2017). Factors Influencing Perceptions and Use of Urban Nature: Surveys of Park Visitors in Delhi. Land, 6(2), 27.https://doi.org/10.3390/land6020027 
Pawinee, I., Kardi, T., Jian, GE \&Kazunori, H. (2005).Interaction of activity involvement and recreational location selection behaviour in Lowland City: A case study of public parks in Saga City. Japan, Journal- Zhejiang University Science.6(8), 900- 906.

Poortinga, W. (2006).Perceptions of the environment, physical activity, and obesity. Social Science \& Medicine, 63(11), 28352846.https://doi.org/10.1016/j.socscimed.2 006.07.018

Pretty, J..Peacock, J., Hine, R., Sellens, M., South, N., Griffin, M. (2007).Green exercise in the UK countryside: Effects on health and psychological well-being, and implications for policy and planning. Journal of Environmental Planning Management, $\quad 50, \quad 211$ 231.http://dx.doi.org/10.1080/0964056060 1156466

Rabiatul Adawiyah Nasir, Sabarinah Sh Ahmad, \& Azni Zain Ahmed. (2013). Physical Activity and Human Comfort Correlation in an Urban Park in Hot and Humid Conditions. Procedia - Social and Behavioral Sciences, 105, 598 - 609. https://doi.org/10.1016/j.sbspro.2013.11.06 3

Sari Mutiara\&Isami., K. (2012).Characteristic of Public Small Park Usage in Asia Pacific Countries: Case Study in Jakarta and Yokohama City.Procedia - Social and Behavioral Sciences, 35, 412 419.https://doi.org/10.1016/j.sbspro.2012.0 2.106

Selhub, E.M.; Logan, A.C. (2012). Your Brain on Nature: The Science of Nature's Influence on Your Health, Happiness and Vitality. New York, NY: John Wiley \& Sons.

Seltenrich, N. (2015). Just what the doctor ordered: Using parks to improve children's health. Environmental Health Perspective, 123, A254-A259.

Siti Rashidah Sakip, Norizan Mt Akhir, \&Siti Syamimi Omar. (2015).Determinant factors of successful public parks in Malaysia.Procedia-Social and Behavioral Sciences, $\quad 170, \quad 422-432$. https://doi.org/10.1016/j.sbspro.2015.01.00 3

Sugiyama, T., Francis, J., Middleton, N.J., Owen, N., Giles-Corti, B. (2010). Associations between recreational walking and attractiveness, size, and proximity of neighbourhood open spaces. American Journal of Public Health, 100 (9), 1752-
1757.

https://doi.org/10.2105/AJPH.2009.182006

Suhardi Maulan (2015). Preferences for usability at Taman Tasik Seremban, Malaysia, ALAM CIPTA: International, Journal of Sustainable Tropical Design Research and Practice, 8, 28-33.

Tabachnick, B. G.,\&Fidell, L. S.(2001).Using multivariate statistics(4th ed.). New York, NY, Harper Collins College Publishers

Tahvanainen, L., Tyrv“ainen, L., Ihalainen,M.,Vuorela, N., Kolehmainen, O.(2001). Forest management and public perceptions: visual versus verbal information. Landscape Urban Planning, 53, 53-70.https://doi.org/10.1016/S01692046(00)00137-7

Takano T, Nakamura K, Watanabe M. (2002). Urban residential environments and senior citizens' longevity in megacity areas: the importance of walkable green spaces. Journal of Epidemiology and Community Health, 56, 913-918. http://dx.doi.org/10.1136/jech.56.12.913

Taylor, B. T., Fernando, P., Bauman, A. E., Williamson, A., Craig, J. C., \& Redman, S. (2011). Measuring the quality of public open space using Google Earth. American journal of preventive medicine, 40(2), 105112.

https://doi.org/10.1016/j.amepre.2010.10.0 24

Ting, O. K. (2001) 'Statement', 25th Special Session of the General Assembly for an Overall Review and Appraisal of the Implementation of the Outcome of the United Nations Conference on Human Settlements (Habitat II), New York.

Von Kursell, A. A. (1997). Replanning Urban Parks. Unpublished Masters of Urban and Rural Planning Thesis, Technical University of Nova Scotia, Halifax, Nova Scotia, Canada.

Wolf, K.L.; Robbins, A. (2015). Metro nature, environmental health, and economic value. Environmental Health Perspective, 123, 390-398. http://doi.org/10.1289/ehp.1408216

Whyte, H.W. (2000).How to Turn a Place Around: A Handbook for Creating Successful Public Space. New York: Project for Public Spaces.

Yang, W. \& Kang, J. (2005).Soundscape and Sound Preferences in Urban Squares: A Case Study in Sheffield.Urban Design, 10(1): $\quad 61$ 80.https://doi.org/10.1080/1357480050006 2395 
Zhang, Y., van Dijk, T., Tang, J., \& Berg, A. E. (2015). Green space attachment and health: A comparative study in two urban neighbourhoods. International journal of environmental research and public health, 12(11), 14342-14363.doi: 10.3390/ijerph121114342 